\title{
Breastfeeding knowledge, attitudes and practice among rural women in Bangladesh: insights from Tungipara village
}

\author{
HASAN HOWLADER ${ }^{A, D, E}$, ASHFIKUR RAHMAN ${ }^{\mathrm{c}, \mathrm{D}}$, MAHAMUDUL HASAN ${ }^{\mathrm{B}, \mathrm{F}}$ \\ ORCID ID: 0000-0002-5517-8557
}

Development Studies Discipline, Khulna University, Bangladesh

A - Study Design, B - Data Collection, C - Statistical Analysis, D - Data Interpretation, E - Manuscript Preparation, F - Literature Search, G - Funds Collection

Summary Background. Breastfeeding is the natural way of feeding an infant with mother's milk by direct nipple contact with the baby's mouth in order to provide nutritional, metabolic and physiological needs, as well as to protect the baby from morbidity and mortality. However, inadequate knowledge and negative attitudes lowers the prevalence rate of breastfeeding and exclusive breastfeeding (EBF) among rural mothers.

Objectives. To assess the level of knowledge, attitudes and practice of breastfeeding among rural women and to determine the factors that affect this practice.

Material and methods. This study was a cross-sectional descriptive study conducted on 130 conveniently selected mothers aged 18-35 years having at least one child (aged 1 week to 6 years). Simple descriptive statistics were used to identify the general characteristics of the participants, where univariate logistic regression was used to determine the factors considering $p$-values less than $<0.01$ and $<0.05$. Results. Most of the women had a positive attitude towards breastfeeding, where $68.46 \%$ of mothers had properly given breast milk to their children up until 6 months, while $91.6 \%$ fed them colostrum; respectively, $78.5 \%$ and $73.1 \%$ of mothers washed their hands and cleaned their baby's mouth before and after the child's mouth contact with the breast. The mother's age and education (OR = $0.428[\mathrm{Cl}=0.176-1.039] p<0.001),(\mathrm{OR}=1.627[\mathrm{Cl}=0.870-3.046] p<0.001)$, the father's education and occupation $(\mathrm{OR}=0.987[\mathrm{Cl}$ $=0.828-1.177] p<0.001),(\mathrm{OR}=0.906[\mathrm{Cl}=0.574-1.429] p<0.005)$ and dwellings structure $(\mathrm{OR}=2.555[\mathrm{Cl}=0.722-9.042] p<0.001)$ are associated with the practice of breastfeeding.

Conclusions. Breastfeeding and EBF should be promoted through primary care and counseling programs together with programs designed to uplift the socio-economic status of rural women.

Key words: knowledge, attitudes, breastfeeding, practice.

Howlader H, Rahman A, Hasan M. Breastfeeding knowledge, attitudes and practice among rural women in Bangladesh: insights from Tungipara village. Fam Med Prim Care Rev 2020; 22(4): 284-290, doi: https://doi.org/10.5114/fmpcr.2020.100432.

\section{Background}

Breastfeeding is the most natural way of feeding an infant with its mother's milk. This occurs by direct nipple contact with the baby's mouth. This is done in order to provide for the nutritional, metabolic and physiological needs of the baby. Breastfeeding is considered as being the best feeding method for infants until the first 6 post-natal months, which has the protective capability of stopping mortality and morbidity [1]. The World Health Organization (WHO) and the United Nations Children's Fund (UNICEF) recommends that within the first hour after birth, infants must be breastfed - and thereafter, for up to six months, infants should exclusively be breastfed with a view to the child obtaining optimal physical growth, mental growth and human development [2].

In rural areas, people - particularly, mothers - tend to be less educated and less conscious about fostering children. Notwithstanding, various studies have already revealed that Bangladeshi mothers are very aware of the value of giving breastmilk to their children. Bangladesh is a country with a high prevalence of breastfeeding as compared to other developing countries. Initially, the Bangladesh Demography \& Health Survey (BDHS2011) reported the rate of Exclusive Breastfeeding (EBF) in Bangladesh was $64 \%$ (2011) and that the rate of early initiation was $43 \%$ (2007). However, the data of the latest BDHS-2014 asserts that $55 \%$ of all children under 6 months of age were exclusively breastfed [3]. Breast milk is the utmost natural source of nutrition for a child's health. According to the WHO, a mother's breast milk offers up to half or more of the child's nutritional needs during the second half of the first year - and up to one-third during their second year of life. UNICEF stressed that it is possible to stop the deaths of 1.3 million of the world's children if they are given breast milk properly from birth up to 6 months; unfortunately, 78 million babies, or 3 out of 5 , are not breastfed within the first hour of delivery [4].

The fourth Millennium Development Goal (MDG: 4) was determined to reduce infant and child mortality by two thirds between 1990 and 2015. Though Bangladesh has achieved unrivaled success in reducing the infant and child mortality rate, they have not reached a rate of zero. This is because so many children still die due to a lack of adequate, nutritious food and proper breastfeeding. A comprehensive, adequate measure needs to be taken for stopping further child mortality.

In regards to promoting the practice of breastfeeding to improve a child's health, a local-level breastfeeding situation assessment would be an essential step that could be conducive to the implementation of location-specific strategies and programs [2]. Inasmuch, the well-nurtured healthy child of today is the healthy human capital of tomorrow. As a result, an appropriate breastfeeding practice can be the first possible effective intervention step taken towards ameliorating child health.

Appropriate breastfeeding means feeding a child the breast milk of their mothers from the very first hour of a baby's birth until 6 months of age, without any outside food and drink, with no discarding of the colostrum; and, at regular intervals, maintaining hygiene issue. In order to practice the appropriate way of feeding breast milk, a mother needs proper knowledge and 
education, access to appropriate information and developed socio-economic conditions [5].

In a poor developing country like Bangladesh, rural mothers are generally not well-educated. Furthermore, their socio-economic status and difficulty in accessing information regarding breastfeeding presents an impediment to their following appropriate breastfeeding practices - even if they are often uncaring about breastfeeding. In such a situation, data regarding breastfeeding knowledge, attitudes and practices can help in taking further steps to promote breastfeeding. Therefore, this study was conducted to assess the mother's knowledge and practices regarding breastfeeding and the factors which influence both.

\section{Objectives}

The present study was intended to assess the level of knowledge regarding breastfeeding, to assess associated attitudes and to assess the practice of breastfeeding, as well as to identify the factors that affect rural mothers engaging in this practice.

\section{Material and methods}

\section{Study design}

The authors conducted a cross-sectional descriptive study using a quantitative data collection technique. The study was conducted among mothers aged $18-35$ years and having at least one child of an age between 1 week to 6 years living in the village of Tungipara, located in the Gopalganj Upazila district of Bangladesh. First, the researchers constructed a structured questionnaire for data collection. Two physicians from the Khulna University Medical Center then revised the study questionnaire and added their comments and suggestions in order to incorporate relevant variables. Afterwards, the questionnaire was pre-tested on 13 mothers in a neighboring village of Tungipara for its accuracy, who were not included as a sample. Finally, the Development Studies Discipline of Khulna University checked the questionnaire and approved it for data collection. The questionnaire had four segments. The first segment was about the socio-biological characteristics of the mothers and their children. The second part was about the mothers' knowledge of EBF. The third section covered the mothers' practice of EBF knowledge. The fourth part was about their attitudes towards breastfeeding. A three-point Likert scale measurement technique was adapted to measure the attitudes of the mothers. Before interviewing the mothers, the aims and objectives of the study were described to the respondents, and their verbal consent was taken.

\section{Setting}

The study was conducted in the village of Tungipara, located in the Gopalganj Upazila district of Bangladesh. Data was collected from the mothers who visited the Tungipara Community Clinic and who were residing in this village between August $1-30,2018$

\section{Participants}

A total of 196 mothers having the inclusion criteria and who - between January and July of 2018 - visited the Tungipara Community Clinic (a primary health care center that provides both preventive and curative services).

\section{Inclusion criteria}

Criterion for inclusion in the study were as follows: Participants were registered mothers of the Tungipara Community Clinic (a primary health care center). They were 18-35 years of age. They had at least one child aged between 1 week to 6 years. They lived in the village of Tungipara (located in the Go- palganj Upazila district of Bangladesh). Lastly, they were breastfeeding their children (whether following a practice of doing so either exclusively or partially). These were the ones included as participants.

\section{Exclusion criteria}

Infants or mothers who were admitted to the hospital - or mothers whose children were not aged 1 week to 6 years - were not included in this study for interviewing.

\section{Variables}

\section{Outcome variable}

The practice of exclusive breastfeeding was the prime dependent variable.

\section{Predictor variables}

The age of the mother, the sex of the children, the mother's education, the father's education, special training in $\mathrm{BF}$, the mother's occupation, the father's occupation, the mode of delivery, the place of delivery, the type of housing and the presence of a sanitary latrine were assessed as potential predictor variables.

\section{Data sources}

Data for each variable of this study was collected through survey methods from the mothers. A face-to-face interview was conducted by the researchers. The measurement of the data was selected from existing literature on the topic.

\section{Bias}

Though the participants in this study were selected conveniently from a list of 196 members of the population of registered mothers, the researchers tried to include participants from all socio-economic backgrounds.

\section{Study size}

A sample of 130 mothers from 196 registered mothers in the Tungipara Community Clinic was calculated, following Krejcie and Morgan [6]. The samples were then selected conveniently from the list of registered mothers, as provided by the community clinic.

\section{Quantitative variables}

The filled-out questionnaires were verified and checked for inaccuracy and incompleteness. The complete questionnaires were then coded manually. The coded data was entered into the Statistical Package for the Social Sciences (SPSS version 20) for analysis.

\section{Statistical methods}

In this study, descriptive statistics such as frequency, percentage, mean, inferential statistics correlation, bivariate and univariate logistic regression were calculated in order to determine the factors. A $p$-value less than $<0.01$ and $<0.05$ was taken into consideration. Meanwhile, a mid-upper arm circumference (MUAC) test was employed in order to examine the nutritional status of the children.

\section{Ethical consideration}

This study was carried out in the partial fulfillment of Bachelor degree in Development Studies Discipline, the internal ethical board of Development Studies Discipline, Khulna University, Bangladesh approved the data collection and publication. 


\section{Results}

Participant's characteristics and descriptive data.

\begin{tabular}{|c|c|c|}
\hline Variables & $n$ & $\%$ \\
\hline $\begin{array}{l}\text { Age of the mother } \\
18-22 \\
23-27 \\
28-32 \\
33-37\end{array}$ & $\begin{array}{l}10 \\
50 \\
65 \\
5\end{array}$ & $\begin{array}{l}7.70 \\
38.46 \\
50.00 \\
3.84\end{array}$ \\
\hline \begin{tabular}{|l} 
Weight of the mother \\
below $45 \mathrm{~kg}$ \\
$46-50 \mathrm{~kg}$ \\
$51-55 \mathrm{~kg}$ \\
above $56 \mathrm{~kg}$ \\
\end{tabular} & $\begin{array}{l}10 \\
43 \\
41 \\
36\end{array}$ & $\begin{array}{l}7.70 \\
33.07 \\
31.54 \\
27.69 \\
\end{array}$ \\
\hline $\begin{array}{l}\text { Educational status of the mother } \\
\text { no formal education } \\
\text { primary level } \\
\text { grades } 6 \text { to } 8 \\
\text { SSC }\left(10^{\text {th }} \text { grade }\right) \\
\text { HSC }\left(12^{\text {th }} \text { grade }\right) \text { and above } \\
\end{array}$ & $\begin{array}{l}5 \\
28 \\
45 \\
30 \\
22 \\
\end{array}$ & $\begin{array}{l}3.84 \\
21.54 \\
34.62 \\
23.08 \\
16.92 \\
\end{array}$ \\
\hline $\begin{array}{l}\text { Educational status of the father } \\
\text { no formal education } \\
\text { primary level } \\
\text { grades } 6 \text { to } 8 \\
\text { SSC }\left(10^{\text {th }} \text { grade }\right) \\
\text { HSC }\left(12^{\text {th }} \text { grade }\right) \text { and above } \\
\end{array}$ & $\begin{array}{l}2 \\
7 \\
37 \\
53 \\
31\end{array}$ & $\begin{array}{l}1.54 \\
5.38 \\
28.46 \\
40.77 \\
23.85 \\
\end{array}$ \\
\hline \begin{tabular}{|l}
$\begin{array}{c}\text { Profession of the mother } \\
\text { housewife } \\
\text { job holder }\end{array}$ \\
\end{tabular} & \begin{tabular}{|l}
110 \\
20 \\
\end{tabular} & $\begin{array}{l}84.70 \\
15.30 \\
\end{array}$ \\
\hline $\begin{array}{l}\text { Profession of the father } \\
\text { business } \\
\text { job holder } \\
\text { shopkeeper } \\
\text { day labor } \\
\text { driver } \\
\text { farmer } \\
\end{array}$ & $\begin{array}{l}73 \\
24 \\
15 \\
6 \\
4 \\
8 \\
\end{array}$ & $\begin{array}{l}56.15 \\
18.46 \\
11.54 \\
4.62 \\
3.07 \\
6.16\end{array}$ \\
\hline $\begin{array}{l}\text { Dwellings by structural type } \\
\text { Pucca } \\
\text { Kutcha } \\
\text { Semi-Pucca }\end{array}$ & $\begin{array}{l}116 \\
4 \\
10 \\
\end{array}$ & $\begin{array}{l}89.23 \\
3.08 \\
7.69\end{array}$ \\
\hline $\begin{array}{l}\text { Location of the delivery of the child } \\
\text { govt. hospital } \\
\text { private health clinic } \\
\text { home }\end{array}$ & \begin{tabular}{|l|}
103 \\
7 \\
20
\end{tabular} & $\begin{array}{l}79.23 \\
5.38 \\
15.39 \\
\end{array}$ \\
\hline $\begin{array}{l}\text { Mode of the delivery of the child } \\
\text { normal (vaginal delivery) } \\
\text { caesarean }\end{array}$ & \begin{tabular}{|l|}
69 \\
61
\end{tabular} & $\begin{array}{l}53.07 \\
46.93\end{array}$ \\
\hline $\begin{array}{l}\text { Biological characteristics of the child } \\
\text { Sex of the child } \\
\text { boy } \\
\text { girls } \\
\end{array}$ & $\begin{array}{l}73 \\
57 \\
\end{array}$ & $\begin{array}{l}56.15 \\
43.85 \\
\end{array}$ \\
\hline
\end{tabular}

The data in Table 1 reveals that the majority of the mothers $-65(50 \%)$ of them - were in the age group of 28-32 years, while $50(38.46 \%)$ of them were from the $23-27$ age group. Of the 130 mothers, $43(33.07 \%)$ of them weighed $46-50 \mathrm{~kg}$. This was slightly less than those of the highest weight -41 mothers (54\%) weighed $51-55 \mathrm{~kg}$. The rest of the mothers -36 mothers $(27.69 \%)$ - weighed over $56 \mathrm{~kg}$. The obtained data exposed that $45(34.62 \%)$ mothers completed grades 6 to 8 , whereas 22 (16.92\%) completed HSC or above (with regard to their level of education). More than $80 \%$ of $110(84.70 \%)$ of the mothers were housewives, while only $20(15.30 \%)$ were jobholders. Of the 130 mothers, $103(79.23 \%)$ of the mothers gave birth to their last children in public hospitals, whereas 7 (5.38\%) did so in the village's private clinic. It was observed that the high- est number of mothers (20) had given birth to their last child in a home (15.39\%). The result revealed that the majority of mothers - 69 mothers (53.07\%) - gave birth to their children by means of a normal (vaginal) delivery, whereas 61 (46.93\%) of them had undergone a cesarean section.

\section{Table 2. Mother's knowledge of breastfeeding $(n=130)$}

\section{Knowledge}

Do you know about Exclusive

Breastfeeding (EBF)?

Is colostrum important for

a baby's health?

Should the baby be given any

liquid besides breast milk before

EBF?

Does breastfeeding give a baby all

the needed nutrients for the first

6 months?

Do you know about the dangers

of bottle feeding?

\begin{tabular}{|l|l|l|}
\hline & $n$ & $\%$ \\
\hline yes & 89 & 68.46 \\
\hline no & 41 & 31.54 \\
\hline yes & 86 & 66.15 \\
\hline no & 44 & 33.85 \\
\hline yes & 9 & 6.92 \\
\hline no & 121 & 93.08 \\
\hline yes & 89 & 68.46 \\
\hline no & 41 & 31.54 \\
\hline yes & 114 & 87.70 \\
\hline no & 16 & 12.30 \\
\hline
\end{tabular}

Proper knowledge is a prerequisite for a mother's placement of her child's mouth in contact with her breast in an ideal manner. Practicing the above knowledge can bring about the best benefit for an infant. A majority of mothers $-68.46 \%$ (89) - had knowledge of EBF. As shown in Table 2, 74.62\% (97) of mothers had fed their infant from their breast, where only $25.38 \%$ (33) did not feed breast milk to their children. Colostrum is important for an infant - a fact which is well recognized by all. The findings presented in the table show that a majority of mothers $-66.15 \%(86)$ - had adequate knowledge regarding the importance of colostrum feeding. However, a majority of mothers $-33.85 \%$ (44) - did not know the importance of colostrum. A majority of the mothers $-93.08 \%$ (121) - knew that for the first 6 months, an infant should not be given anything besides BF. Meanwhile, only a small number of mothers $-6.92 \%$ (9) - did not known this. A majority of the mothers $-68.46 \%$ (89) - had specific knowledge as to the nutritional value of breast milk, while $31.54 \%$ (41) did not know that breast milk can provide all the nutrients required for children's health. It is also observed that $87.70 \%$ (114) of mothers had knowledge of the disadvantageous nature of bottle feeding, while $12.30 \%$ (16) answered that they had no knowledge of this.

Table 3. Breastfeeding practices of mothers $(n=130)$

\begin{tabular}{|l|l|l|l|}
\hline & & $n$ & $\%$ \\
\hline \multirow{2}{*}{$\begin{array}{l}\text { Did you give colostrum to your } \\
\text { baby? }\end{array}$} & yes & 120 & 92.31 \\
\cline { 2 - 4 } & no & 10 & 7.69 \\
\hline \multirow{2}{*}{ Did you practice EBF? } & yes & 120 & 92.31 \\
\cline { 2 - 4 } & no & 10 & 7.69 \\
\hline \multirow{2}{*}{$\begin{array}{l}\text { Did you initiate breastfeeding in } \\
\text { the first hour of delivery? }\end{array}$} & yes & 89 & 68.46 \\
\cline { 2 - 4 } & no & 41 & 31.54 \\
\hline \multirow{2}{*}{$\begin{array}{l}\text { Did you give up BF before your } \\
\text { baby reached the age of 6 } \\
\text { months? }\end{array}$} & yes & 44 & 33.85 \\
\cline { 2 - 4 } & no & 86 & 66.15 \\
\hline \multirow{2}{*}{$\begin{array}{l}\text { Did you face any breast problems } \\
\text { during BF? }\end{array}$} & yes & 29 & 21.54 \\
\cline { 2 - 4 } & no & 101 & 77.69 \\
\hline \multirow{2}{*}{$\begin{array}{l}\text { Did you offer pre-lacteal food to } \\
\text { your baby? }\end{array}$} & yes & 44 & 33.85 \\
\cline { 2 - 4 } & no & 86 & 66.15 \\
\hline \multirow{2}{*}{$\begin{array}{l}\text { Do you wash your hands before } \\
\text { breastfeeding? }\end{array}$} & yes & 102 & 78.5 \\
\cline { 2 - 4 } & no & 28 & 21.5 \\
\hline \multirow{2}{*}{$\begin{array}{l}\text { Do you clean your baby's mouth } \\
\text { after breastfeeding? }\end{array}$} & yes & 95 & 73.10 \\
\cline { 2 - 4 } & no & 35 & 26.90 \\
\hline
\end{tabular}


Table 3 represents that within 3 days after delivery, the majority of mothers $-92.31 \%$ (120) - fed their newborn from their breast. The findings also revealed that after the delivery of their child, $68.46 \%$ of mothers (89) initiated the giving of breast milk to their child. However, $33.85 \%$ (44) had not initiated breastfeeding due to physical illness or due to breast milk not being produced or being inadequate. It is observed from the data in Table 3 that $66.15 \%(86)$ of mothers had no plan to give up breastfeeding until the after the first 6 months, but a small portion $-33.85 \%$ (44) - initiated the giving up of breastfeeding due to various problems (i.e. the inadequacy of breast milk, milk not coming out adequately, itching, etc.). It was found in the current study that mothers who appropriately breastfed their children were less likely to report any breastfeeding problem during the first month after the child's birth. Additionally, a majority of mothers $-77.69 \%$ (101) - did not face any problems during breastfeeding. Meanwhile, a small number of mothers $-21.54 \%$ (29) - reported that they had faced such problems. As the mothers were very conscious about bottle feeding, the results indicate that $66.15 \%$ (86) of mothers had not given their infant any pre-lacteal food, while $33.85 \%$ (44) of them were bound to give lacteal food because of the aforesaid problems. Among the study's participants, as many as $78.5 \%$ (102) of mothers washed their hands before feeding their baby, whereas $21.5 \%$ (28) had not done so. The present study shows that $73.10 \%$ (95) of mothers had observed the practice of cleaning their children's mouths after feeding them breast milk, whereas the rest of the mothers had not practiced this.

Table 4 presents the responses of the mothers' attitudes towards breastfeeding. Over $90 \%$ (119) of mothers - with a mean score of $(\mathrm{MS})=1.16$ - pointed out their strong views about the importance of a mother's milk for children's health. Meanwhile, $73.85 \%(96)$ of mothers (MS $=1.33$ ) strongly agreed that BF can protect the baby from infections or diseases. $86.15 \%$ (112) of mothers (MS $=1.12$ ) were neutral with regard to the cheapness and availability of breast milk, whereas $66.92 \%$ (87) of mothers (MS $=1.11$ ) strongly agreed that it is God-gifted and natural. A very large portion of mothers $-83.8 \%$ (109) (MS = 1.25) - gave their opinion that proper breastfeeding could be conducive to preventing maternal breast cancer.

\begin{tabular}{|c|c|c|c|c|}
\hline \multirow[t]{2}{*}{ Statements } & SA & D & N & $\begin{array}{l}\text { Mean } \\
\text { Score }\end{array}$ \\
\hline & 1 & 2 & 3 & \\
\hline $\begin{array}{l}\text { BF is nutritious for } \\
\text { a baby }\end{array}$ & $\begin{array}{l}119 \\
(91.5 \%)\end{array}$ & \begin{tabular}{|l}
9 \\
$(6.92 \%)$
\end{tabular} & \begin{tabular}{|l}
2 \\
$(1.54 \%)$
\end{tabular} & 1.16 \\
\hline $\begin{array}{l}\text { BF protects a baby } \\
\text { from infections }\end{array}$ & $\begin{array}{l}96 \\
(73.85 \%)\end{array}$ & $\begin{array}{l}23 \\
(17.69 \%)\end{array}$ & \begin{tabular}{|l|}
11 \\
$(8.46 \%)$
\end{tabular} & 1.33 \\
\hline $\begin{array}{l}\text { Breast milk is cheap } \\
\text { and available }\end{array}$ & $\begin{array}{l}10 \\
(7.69 \%)\end{array}$ & \begin{tabular}{|l}
6 \\
$(4.62 \%)$
\end{tabular} & \begin{tabular}{|l|}
112 \\
$(86.15 \%)$
\end{tabular} & 1.12 \\
\hline $\begin{array}{l}\text { Breast milk is natural } \\
\text { and God-gifted }\end{array}$ & $\begin{array}{l}87 \\
(66.92 \%)\end{array}$ & \begin{tabular}{|l|}
13 \\
$(10.00 \%)$
\end{tabular} & \begin{tabular}{|l|}
30 \\
$(23.08 \%)$
\end{tabular} & 1.11 \\
\hline $\begin{array}{l}\text { BF could prevent ma- } \\
\text { ternal breast cancer }\end{array}$ & $\begin{array}{l}109 \\
(83.8 \%)\end{array}$ & $\begin{array}{l}9 \\
(6.9 \%)\end{array}$ & $\begin{array}{l}12 \\
(9.2 \%)\end{array}$ & 1.25 \\
\hline $\begin{array}{l}\text { Children should be } \\
\text { given other food aside } \\
\text { from BF before } 6 \\
\text { months }\end{array}$ & $\begin{array}{l}110 \\
(84.6)\end{array}$ & $\begin{array}{l}11 \\
(8.46 \%)\end{array}$ & $\begin{array}{l}9 \\
(6.92 \%)\end{array}$ & 1.24 \\
\hline
\end{tabular}

S A - strongly agree, D - disagree, N - neutral, BF - breastfeeding.

Factors influencing the practice of EBF until 6 months of age were determined by employing a univariate logistic regression model. The chi-square test of association was included in univariate logistic regression analysis. With regard to better breastfeeding practice, the following factors were found to influence the EBF of mothers: the age of the mother $(\mathrm{OR}=0.428,[\mathrm{Cl}=0.176-1.039]$ $p<0.001)$, the mother's education (OR $=1.627$ [0.870-3.046] $p<0.001)$, the father's education (OR $=0.987$ [0.828-1.177] $p<0.001)$, the father's occupation (OR $=0.906$ [0.574-1.429] $p<$ $0.005)$, the type of housing (OR $=2.555[0.722-9.042] p<0.001)$.

\begin{tabular}{|c|c|c|c|c|c|c|c|c|}
\hline & & \multicolumn{4}{|c|}{ Weight of the child (kilograms) } & \multirow[b]{2}{*}{ Total } & \multirow[b]{2}{*}{$p<0.01$} & \multirow[b]{2}{*}{$r^{2}$} \\
\hline & & $<11-15 \mathrm{~kg}$ & $16-20 \mathrm{~kg}$ & $21-25 \mathrm{~kg}$ & $\geq 26 \mathrm{~kg}$ & & & \\
\hline \multirow[t]{2}{*}{ BF Status } & yes & 0 & 7 & 32 & 58 & 97 & \multirow{3}{*}{ Sig. } & \multirow{3}{*}{$0.710^{* *}$} \\
\hline & no & 2 & 11 & 20 & 0 & 33 & & \\
\hline \multirow{3}{*}{\multicolumn{2}{|c|}{ Total }} & 2 & 18 & 52 & 58 & 130 & & \\
\hline & & \multicolumn{4}{|c|}{ Height of the child (12 inches $=0.3048$ meter $(\mathrm{m})$ ) } & \multirow{2}{*}{ Total } & & \\
\hline & & $<0.30 \mathrm{~m}$ & $0.46-0.61 \mathrm{~m}$ & $0.64-0.76 \mathrm{~m}$ & $0.79 m \geq 0.91 m$ & & & \\
\hline \multirow[t]{2}{*}{ BF Status } & yes & 2 & 25 & 3 & 67 & 97 & \multirow{3}{*}{ Sig. } & \multirow{3}{*}{$0.658 * *$} \\
\hline & no & 5 & 1 & 17 & 10 & 33 & & \\
\hline \multirow{3}{*}{\multicolumn{2}{|c|}{ Total }} & 7 & 26 & 20 & 77 & 130 & & \\
\hline & & \multicolumn{4}{|c|}{ Measurement of nutritional status by using MUAC } & \multirow{2}{*}{ Total } & & \\
\hline & & Green & Yellow & Red & & & & \\
\hline \multirow[t]{2}{*}{ BF Status } & yes & $73(56.13 \%)$ & $19(14.62 \%)$ & $5(3.85 \%)$ & & 97 & \multirow{3}{*}{ Sig. } & \multirow{3}{*}{$0.602^{* *}$} \\
\hline & no & $9(6.92 \%)$ & $11(8.50 \%)$ & $13(10 \%)$ & & 33 & & \\
\hline \multicolumn{2}{|l|}{ Total } & $82(63.10 \%)$ & $30(23.10 \%)$ & $18(13.85 \%)$ & & 130 & & \\
\hline
\end{tabular}

Table 6. Logistic regression and univariate analysis factors affecting the success of breastfeeding practice among mothers $(n=130)$

\begin{tabular}{|l|l|l|l|l|}
\hline \multirow{2}{*}{ Covariates } & \multicolumn{2}{|l|}{ Mother breastfeeding practice } & & \multicolumn{2}{l|}{ OR (CI) } \\
\cline { 2 - 5 } & Feed & Don't feed & $f$ & 2.850 \\
$18-22$ & $6(60 \%)$ & $4(40 \%)$ & & $0.428[0.176-1.039]^{* *}$ \\
$23-27$ & $32(64 \%)$ & $18(36 \%)$ & & \\
$28-32$ & $54(83.08 \%)$ & $11(16.02 \%)$ & & \\
$33-37$ & $5(100 \%)$ & - & & \\
\hline
\end{tabular}




\begin{tabular}{|c|c|c|c|c|}
\hline \multirow[t]{2}{*}{ Covariates } & \multicolumn{2}{|c|}{ Mother breastfeeding practice } & \multirow[b]{2}{*}{$f$} & \multirow[b]{2}{*}{ OR (Cl) } \\
\hline & Feed & Don't feed & & \\
\hline $\begin{array}{l}\text { Sex of the child } \\
\text { male } \\
\text { female }\end{array}$ & $\begin{array}{l}54 \text { (73.97\%) } \\
43 \text { (75.44\%) }\end{array}$ & $\begin{array}{l}19 \text { (26.03\%) } \\
14 \text { (24.56\%) }\end{array}$ & 0.095 & $0.943[0.325-2.742]$ \\
\hline $\begin{array}{l}\text { Education of the mother } \\
\text { no formal education } \\
\text { primary level } \\
\text { grades } 6 \text { to } 8 \\
\text { SSC-HSC }\left(10^{\text {th }}-12^{\text {th }}\right) \\
\end{array}$ & \begin{tabular}{|l|}
$1(20 \%)$ \\
$23(82.1 \%)$ \\
$30(66.7 \%)$ \\
$20(90.91 \%)$ \\
\end{tabular} & \begin{tabular}{|l|}
$4(80.0 \%)$ \\
$5(17.9 \%)$ \\
$15(33.3 \%)$ \\
$2(9.09 \%)$ \\
\end{tabular} & 3.505 & $1.627[0.870-3.046]^{* *}$ \\
\hline $\begin{array}{l}\text { Education of the father } \\
\text { no formal education } \\
\text { primary level } \\
\text { grades } 6 \text { to } 8 \\
\text { SSC }\left(10^{\text {th }}\right) \\
\text { HSC }\left(12^{\text {th }}\right) \text { and above }\end{array}$ & \begin{tabular}{|l}
- \\
$6(85.71 \%)$ \\
$31(82.1 \%)$ \\
$38(66.7 \%)$ \\
$21(14.28 \%)$ \\
\end{tabular} & \begin{tabular}{|l}
$2(100 \%)$ \\
$1(14.29 \%)$ \\
$6(17.9 \%)$ \\
$15(33.3 \%)$ \\
$10(85.71 \%)$ \\
\end{tabular} & 5.703 & $0.987[0.828-1.177]^{* *}$ \\
\hline $\begin{array}{l}\text { Having training in } B F \\
\text { yes } \\
\text { no }\end{array}$ & $\begin{array}{l}27(93.1 \%) \\
70(76.92 \%)\end{array}$ & $\begin{array}{l}12(6.9 \%) \\
21(33.08 \%)\end{array}$ & 0.218 & 0.675 [0.292-1.559] \\
\hline $\begin{array}{l}\text { Mother's occupation } \\
\text { housewife } \\
\text { jobholder }\end{array}$ & $\begin{array}{l}77(59.23 \%) \\
20(15.38 \%) \\
\end{array}$ & $\begin{array}{l}33(25.38 \%) \\
-\end{array}$ & - & - \\
\hline $\begin{array}{l}\text { Father's occupation } \\
\text { business } \\
\text { job holder } \\
\text { shopkeeper } \\
\text { day labor } \\
\text { driver } \\
\text { farmer }\end{array}$ & \begin{tabular}{|l}
$56(76.7 \%)$ \\
$21(87.5 \%)$ \\
$9(60.0 \%)$ \\
$4(66.7 \%)$ \\
$2(50.0 \%)$ \\
$5(62.5 \%)$ \\
\end{tabular} & $\begin{array}{l}17(23.3 \%) \\
3(12.5 \%) \\
6(40.0 \%) \\
2(33.3 \%) \\
2(50.50) \\
3(37.5 \%) \\
\end{array}$ & 1.24 & 0.906 [0.574-1.429]* \\
\hline $\begin{array}{l}\text { Mode of delivery } \\
\text { normal } \\
\text { caesarean }\end{array}$ & $\begin{array}{l}50(38.46 \%) \\
47(36.15 \%) \\
\end{array}$ & $\begin{array}{l}19(14.62 \%) \\
14(10.77 \%) \\
\end{array}$ & 0.355 & $0.460[0.151-1.397]$ \\
\hline $\begin{array}{l}\text { Place of delivery } \\
\text { govt. hospital } \\
\text { private health clinic } \\
\text { home }\end{array}$ & \begin{tabular}{|l|}
$75(72.82 \%)$ \\
$6(85.71 \%)$ \\
$16(80 \%)$ \\
\end{tabular} & \begin{tabular}{|l|}
$28(37.18 \%)$ \\
$1(14.29 \%)$ \\
$4(20 \%)$ \\
\end{tabular} & 0.461 & $0.586[0.285-1.205]$ \\
\hline $\begin{array}{l}\text { Dwellings by structural type } \\
\text { Pucca } \\
\text { Kutcha } \\
\text { Semi-Pucca } \\
\end{array}$ & \begin{tabular}{|l|}
$92(79.31 \%)$ \\
$1(25 \%)$ \\
$4(40 \%)$ \\
\end{tabular} & \begin{tabular}{|l|}
$24(20.69 \%)$ \\
$3(75 \%)$ \\
$6(60 \%)$ \\
\end{tabular} & 3.990 & $2.555[0.722-9.042]^{* *}$ \\
\hline $\begin{array}{l}\text { Using a sanitary latrine } \\
\text { yes } \\
\text { no }\end{array}$ & $\begin{array}{l}87 \text { (72.5\%) } \\
12(100 \%)\end{array}$ & $\begin{array}{l}33(27.5 \%) \\
-\end{array}$ & 9.172 & - \\
\hline
\end{tabular}

Sig. at $\left(p<0.01^{* *}-p<0.005^{*}\right)$.

The study indicates that the majority of mothers had good knowledge of the advantages of breastfeeding. Table 6 elucidates the results of the MUAC. The large correlation value illustrates the strong positive relationship between breastfeeding and the children's physical growth. This relationship is statistically significant, based on its $p$-value being $p<0.01$. $P$-values of less than 0.01 were considered as being significant [7]. In addition, the MUAC results illustrate the children's nutritional condition. As delineated in the table, the data shows that only a very few (9) children acquired "in-the-green" (green) nutritional status who did not imbibe their mother's breast milk, whereas (73) children with had "in-the-green" (green) nutritional status who did weaning from their mother's breast. An analysis of the collected data reveals that a red and yellow status was acquired by a higher number of children who had not been given breast milk during the first 6 months of life.

\section{Discussion}

A mother's milk is very essential for an infant. The study's findings assert that $68.46 \%$ of these Bangladeshi mothers had specific knowledge of the nutritional value of breast milk. A study conducted in Nepal, United Arab Emirates found that only $41 \%$ of women believed that breast milk is conducive for the proper growth of a child and that it fights against infection $[8,9]$. On the other hand, in Ethiopia, $72.5 \%$ of mothers had knowledge of weaning [10]. The study shows that $74.62 \%$ of mothers gave breast milk to their infant. This finding is in line with the other findings from Jordan (77\%), Madagascar (70\%), Zambia (74\%), Ghana (79\%) and Bolivia (65\%) [11-13].

Most of the rural mothers are well knowledgeable about breastfeeding, and $66.15 \%$ of mothers have adequate knowledge regarding the importance of colostrum feeding. A large majority of the women practiced exclusive breastfeeding (92.31\%). A previous study had found that $51.2 \%$ of mothers had good knowledge of EBF [8].

The present study demonstrates that $91.6 \%$ of mothers feed colostrum to their baby - and that within 3 days after delivery, 91.53\% of the mothers fed their child from their breast. This finding coincides with a study conducted in India, which showed that $91 \%$ of mothers gave colostrum to their infant and that $57 \%$ initiated breastfeeding within 1 hour of delivery [14], however 
$60 \%$ of the studied women still discard colostrum [15]. Women who have previous training have better knowledge and practice of breastfeeding. Rahman et al. conducted a study in Bangladesh that revealed that mothers who received antenatal care training had a lower risk of terminating breastfeeding until 6 months after the birth period [16]. Thus, physicians in primary health care centers can take a leading role in promoting breastfeeding through providing counseling and training for rural mothers.

As previously stated, the rural mothers of Bangladesh have had various limitations imposed upon the continuation of exclusive breastfeeding. Women's education and improvement in socioeconomic status - which can be achieved by incomegenerating activities - are to be encouraged [5]. Institutional deliveries must be scaled up to $100 \%$ through the involvement of grassroots-level workers who can reach the farthest corners of a village and promote institutional deliveries [5].

Breastfeeding practice is associated with the socioeconomic status of the mothers, as well as the family. Several studies have already addressed some covariates $[11,17,18]$ which affect the EBF of mothers. This study also found a positive attitude towards breastfeeding, similar to a finding of a study conducted in Abu Dhabi, United Arab Emirates, where $20.9 \%$ of mothers were found to have a good attitude towards breastfeeding [12].

The results of univariate logistic regression analyses revealed that among 9 variables, 5 were potentially associated with a breastfeeding mother's practice of breastfeeding to a degree which is statistically significant at $p<0.01$ and $<0.05$. These 5 factors are the mother's age $(p<0.01 / f=2.850)$, education $(p<0.01 / f=3.505)$, the father's education $(p<0.01 / f=5.703)$, occupation $(p<0.05 / f=1.24)$ and the type of housing $(p<0.01 / \mathrm{f}$ = 3.990). Higher-educated women have better knowledge about breastfeeding and breast cancer [19].

Due to recent improvements in the field of medicine and medical science, all aspects of healthcare facilities have developed and changed $[20,21]$. Therefore, it is thus suggested that the government and related authorities should invest additional efforts in providing adequate knowledge to mothers. Doing so may lead to a significant improvement in breastfeeding practices, not only in Bangladesh but also globally. Breastfeeding is not only a maternal decision but also one influenced by family, health care providers and the community, as well as the government. This study was carried out with the data of enlisted mothers (taken from the local community health center) who practiced exclusive breastfeeding. Community health workers, as well as the family, are the primary actors in fostering EBF among mothers, with a view to the right of the child to healthy nutrition. Therefore, this study would be considered as being a tool conducive for enhancing the way that primary health care facilities located among communities of rural mothers care for those mothers.

\section{Limitations of the study}

This study was conducted in a small rural community with 130 mothers. The convenient sampling may have a sampling bias. Using a close-ended structured questionnaire may not reflect the exact knowledge, attitudes and practices of breastfeeding among mothers.

\section{Conclusions}

The majority of the women living in a rural setting within Bangladesh are knowledgeable and possess positive attitudes towards practicing breastfeeding. Breastfeeding knowledge, attitudes and practices are factors associated with the age, education and occupation of the parents, the sex of the baby, the manner in which the child was delivered, the location in which the child was delivered and the dwelling place. In order to have well-developed knowledge, positive attitudes and proper practices among all rural women, the study's findings demand more awareness (and fundraising programs) through media, advocacy, campaigns and girl's education aligned with national health programs. Family physicians in Maternal and Child Health $(\mathrm{MCH})$ clinics or community clinics should arrange breastfeeding training for adolescents and young mothers and provide more counseling services in order to ensure exclusive breastfeeding and overall breastfeeding. The results of the study may help policymakers in designing and formulating breastfeeding policies and programs.

Source of funding: This work was funded from the authors' own resources.

Conflicts of interest: The authors declare no conflicts of interest.

\section{References}

1. Picciano MF. Nutrient composition of human milk. Pediatr Clin North Am 2001; 48(1): 53-67.

2. World Health Organization (WHO), United Nations Children's Fund (UNICEF). Global strategy for infant and young child feeding. Geneva, Switzerland: WHO; 2003. Available from URL: https://www.who.int/nutrition/publications/infantfeeding/9241562218/en/.

3. National Institute of Population Research and Training (NIPORT), Mitra and Associates and II, 2016. Bangladesh Demographic and Health Survey 2014. Dhaka, Bangladesh, and Rockville, Maryland, USA: NIPORT; 2016. Available from URL: https://dhsprogram.com/ pubs/pdf/FR311/FR311.pdf.

4. World Health Organization. Maternal, newborn, child and adolescent health (MNCAH) data portal. Geneva, Switzerland: WHO [cited 6.08.2018]. Available from URL: http://www.who.int/maternal_child_adolescent/en/.

5. Ashwini S. Comparison of breastfeeding practices among urban and rural mothers: a cross-sectional study. Int J Med Public Health 2014; 4(1), doi: 10.4103/2230-8598.127172.

6. Krejcie RV, Morgan DW. Determining sample size for research activities. Educ Psychol Meas 1970; 30(3): 607-610.

7. Bażydło M, Giezek M, Zabielska P, et al. The phenomenon of domestic violence against children in north-western Poland. Fam Med Prim Care Rev 2018; 20(2): 106-111, doi: 10.5114/fmpcr.2018.76451.

8. Al Ketbi MI, Al Noman S, Al Ali A, et al. Knowledge, attitudes, and practices of breastfeeding among women visiting primary healthcare clinics on the island of Abu Dhabi, United Arab Emirates. Int Breastfeed J 2018; 13(1): 26.

9. Joshi S, Barakoti B, Lamsal S. Colostrum feeding: knowledge, attitude and practice in pregnant women in a Teaching Hospital in Nepal. Int J Mol Med 2012; 3(8): 1-14.

10. Bekele A, Berhane Y. Weaning in Butajira, South Ethiopia: a study on mother's knowledge and practice. Ethiop Med J 1998; 36(1): 37-45.

11. Setegn T, Belachew T, Gerbaba M, et al. Factors associated with exclusive breastfeeding practices among mothers in Goba district, southeast Ethiopia: a cross-sectional study. Int Breastfeed J 2012; 7(1): 17.

12. Oweis A, Tayem A, Froelicher ES. Breastfeeding practices among Jordanian women. Int J Nurs Pract 2009; 15(1): 32-40.

13. Morrow A. Community-based strategies for breastfeeding promotion and support in developing countries. Geneva, Switzerland: World Health Organization; 2003. Available from URL: https://apps.who.int/iris/handle/10665/42859. 
14. Faruque AS, Ahmed AM, Ahmed T, et al. Nutrition: basis for healthy children and mothers in Bangladesh. J Health Popul Nutr 2008; 26(3): 325-339.

15. Patro S, Nanda S, Sahu R. Infant feeding practices of Paroja, a tribal community of Orissa. Stud Home and Comm Sci $2012 ; 6(1): 21-25$.

16. Rahman M, Mizan S, Safii R, et al. Are the urban poor satisfied with health care services for child delivery? Evidence from an Urban Primary Health Care (UPHC) project in Bangladesh. Fam Med Prim Care Rev 2018; 20(2): 159-166, doi: 10.5114/fmpcr.2018.76461.

17. Joshi PC, Angdembe MR, Das SK, et al. Prevalence of exclusive breastfeeding and associated factors among mothers in rural Bangladesh: a cross-sectional study. Int Breastfeed J 2014; 9(1): 7.

18. Nishimura H, Krupp K, Gowda S, et al. Determinants of exclusive breastfeeding in rural South India. Int Breastfeed J 2018; $13(1)$ : 40.

19. Al Shahrani AS, Faraj S, Alhargan A, et al. Factors affecting the age at menopause among Saudi women in Riyadh, SA: a cross-sectional study. Fam Med Prim Care Rev 2018; 20(1): 55-60, doi: 10.5114/fmpcr.2018.73704.

20. Aoun A, Al Hayek S, El Jabbour F. The need for a new model of the physician-patient relationship: a challenge for modern medical practice. Fam Med Prim Care Rev 2018; 20(4): 379-384, doi: 10.5114/fmpcr.2018.79351.

21. Hassan AA, Taha Z, Ahmed MA, et al. Assessment of initiation of breastfeeding practice in Kassala, Eastern Sudan: a community-based study. Int Breastfeed J 2018; 13(1): 34.

Tables: 6

Figures: 0

References: 21

Received: 26.11 .2018

Reviewed: 3.02.2019

Accepted: 23.10.2019

Address for correspondence:

Ashfikur Rahman, MA

Studies Discipline Khan

Jahan Ali Hall Room No. 431

Khulna University

Khulna-9208

Bangladesh

Tel.: +880 1521337300

E-mail: ashfikurr@gmail.com 